\title{
German science body complains of excessive regulation of research
}

Munich. The over-regulation of science in Germany is undermining the efficiency with which research is carried out, and could threaten the country's scientific competitiveness, according to a report from the Deutsche Forschungsgemeinschaft (DFG) - the German Science Council - which is due to be published next month.

An interdisciplinary group of experts appointed by the DFG to look at legal restrictions on researchers points out that laws governing activities such as embryo research, data protection and the use of laboratory animals and genetic technologies are much stricter in Germany than in other countries.

In addition, it says that civil servants enforcing the laws can be excessively zealous, often unfairly denying or delaying the approval of scientific experiments. In 1993, for example, local authorities responsible for licensing genetic engineering experiments twice ignored the recommendations of the Central Committee for Biological Safety, which evaluates experimental protocols, and required extra safety precautions, leading to additional restrictions and paper work.

The report also points out that government officials similarly overrode scientific advisers when, in 1992, they denied a licence to researchers at the University of Kiel who had received a contract from the federal office of forestry and agriculture to find more efficient ways to exterminate brown rats during periods of infestation. The officials involved had argued that plans to catch and tag 40 rats, in order to monitor their movements in the wild, would inflict unjustifiable stress on the rats.

Scientists argue that such cases of official zeal undermine the 'freedom of research' that is guaranteed in Germany's postSecond-World-War constitution. Two years ago, the federal constitutional court ruled in a test case that licensing authorities did not have the competence to assess the scientific aims of a research project. Nevertheless, the DFG report says that federal and regional officials continue to impose their moral judgements on projects.

Many feel that this tendency increases the problem of long delays in licensing procedures. Germany's genetic engineering regulations were recently changed to speed up the average time of licence approval. In theory, this should reduce the average time for approval from ten weeks to six. But in practice, says the report, this period can be extended by officials who have the right to request further information at any point during the application procedure.

Such licensing delays cause particular difficulties for biologists using animals in

experiments. According to a survey carried out by Peter Gruss, a molecular geneticist at the Max Planck Institute for Biophysical Chemistry in Göttingen, scientists have to wait an average of five months for a licence for such experiments. "This means that, as experimentalists, we cannot react to a scientific report for nearly half a year," he says. "That is detrimental to our competitiveness."

The report points out a further problem, that laws designed primarily for industry such as those governing emissions and chemical usage and disposal - also apply to

\section{Hydrogen research}

Washington. The recent rapid expansion in US support for research into the use of hydrogen as a fuel could come to a sudden end when Robert Walker (Republican, Pennsylvania), chair of the Science Committee in the House of Representatives, retires

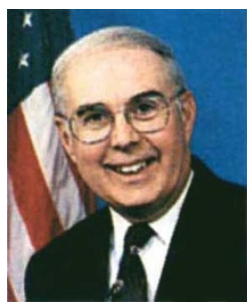

Walker: has backed long crusade in November, the annual meeting of the National Hydrogen Association was told last week.

Spending on hydrogen research at the Department of Energy (DOE) has shot up from just over $\$ 1$ million in 1993 to $\$ 14$ mil-

lion this year, largely as a result of Walker's relentless support. In the same period, more substantial programmes for research into other renewable energy sources have been sharply curtailed: support for solar energy, for example, fell this year from $\$ 259$ million to $\$ 192$ million.

Alan Lloyd of the Desert Research Institute, Reno, Nevada, the next chairman of the DOE's hydrogen advisory board, told last week's meeting that unless supporters of hydrogen research organize themselves much more effectively, "there's going to be a vacuum" when Walker leaves.

The Clinton administration does not see hydrogen as a priority, and has requested that its budget be cut back to $\$ 11$ million next year. "There is a major gap between the Department of Energy's public statements on hydrogen, and its budget requests to Congress," says Lloyd. Neil Rossmeissl, hydrogen programme manager at the DOE, concedes that the department is "providing the minimum amount of funding needed to keep this technology moving".

The House has passed a bill, sponsored by Walker, that would authorize $\$ 100$ mil- research, making the approval process for new facilities, for example, both complicated and lengthy.

The DFG report suggests that such laws should be modified to match the actual conditions under which research facilities operate. It points out, for example, that while industrial companies tend to produce large amounts of a relatively small number of chemicals, a research laboratory tends to have small amounts of a large number of chemicals. Yet both are treated equally by the authorities when it comes to applying for an operating licence.

Alison Abbott

\section{'facing a vacuum'}

lion for hydrogen research over three years. A companion measure in the Senate has bipartisan sponsorship from Jon Kyl (Republican, Arizona) and Tom Harkin (Democrat, Iowa). There is a reasonable prospect that the Senate, which rarely bothers with research authorization bills, will pass the bill in recognition of Walker's long crusade for hydrogen. But even that would not guarantee future funding.

Hydrogen advocates want research at every stage of a complex energy chain, from electric production of hydrogen through its storage, transportation and distribution, as well as on fuel cells and engines, and the vehicles they would power. Such challenges are mostly technical rather than scientific. But Walker calls them "basic research", arguing that "we are not picking a technology, we are picking an area of study" which

\section{IMAGE UNAVAILABLE FOR COPYRIGHT REASONS}

End of a dream? hydrogen's potential suffered a setback when the Hindenburg exploded in 1937

has "been dramatically under-emphasized by the Department of Energy".

Kazukiyo Okano, director of research at Japan's World Energy Network programme, told the meeting that Japan will spend $\$ 18$ million this year on hydrogen research: it is undertaking an accelerating, \$100-million research programme in the period 1993-98, which may lead on to a \$3-billion technology development and demonstration programme.

Colin Macilwain 